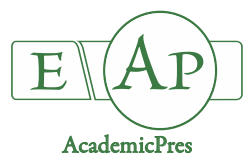

Available online: www.notulaebotanicae.ro

\title{
Potential Transference of CP4 EPSPS to Weed Species from Genetically Modified Gossypium hirsutum in Northern Mexico
}

\author{
Amada TORRES ${ }^{1}$, Juan José REYES-PÉREZ ${ }^{2,3}$, \\ Cándido MÁRQUEZ-HERNÁNDEZ ${ }^{4 \dagger}$, Josué ESTRADA-ARELLANO ${ }^{4}$, \\ Juan Ramón ESPARZA-RIVERA5, Pablo PRECIADO-RANGEL ${ }^{6}$, \\ Bernardo MURILLO-AMADOR ${ }^{1 *}$
}

\author{
${ }^{1}$ Centro de Investigaciones Biológicas del Noroeste, S.C. Av. Instituto Politécnico Nacional 195, Playa Palo de Santa Rita Sur. La Paz, Baja \\ CaliforniaSur, Mexico; asalazar@cibnor.mx; bmurillo04@cibnor.mx (*correspondingauthor) \\ ${ }^{2}$ Universidad Técnica de Cotopaxi.Extensión La Mana, Ecuador;jjreyesp1981@gmail.com \\ ${ }^{3}$ Universidad Técnica Estatal de Quevedo.Quevedo,Los Rios, Ecuador;jjreyesp1981@gmail.com \\ ${ }^{4}$ Universidad Juárez del Estado de Durango, Facultad de Ciencias Biológicas, Gómez Palacio, Durango, Mexico \\ ${ }^{5}$ Universidad Juárez del Estado de Durango, Facultad de Ciencias Quimicas, Gómez Palacio, Durango, \\ Mexico;j.estradarellano@gmail.com;jresparza02001@yahoo.com \\ 'Instituto Tecnológico de Torreón, Torreón, Coabuila, Mexico;ppreciador@yahoo.com.mx \\ † Cándido Márquez-Hernández, our colleague passed away on May 9, 2016 in a tragic car accident. He will be sorely missed by us. Thispaper was published in his memory
}

\begin{abstract}
The family of enzymes 5-enolpiruvil shikimato-3-phosphate synthase (EPSPS) is found in plants and microorganisms. The substrates of this enzyme are phosphoenolpyruvate (PEP) and 3-phospho-shikimate and their products are phosphate and 5enolpyruvylshikimate-3-phosphate that is the biological target of the herbicide glyphosate, which is used in genetically modified crops. The interaction between cultivated genetically modified plants (GMP) and wild plant species could be a transference source of transgenes. Presence of transgenes could be cause and adverse environmental impact on non-target organisms. Gossypium hirsutum genotype Bollgard II" is a GMP with tolerance to herbicide glyphosate and it has been cultivated during 20 years in Mexico and the possibility to gene flow primary in congeners of the Malvaceae family is possible. The objective of this study was to quantify and identify weed species associated to genetically modified cotton fields and to detect the present of glyphosate-insensitive EPSP synthases (CP4 EPSPS) in these species. The results showed that plants of the families Amaranthaceae, Asteraceae, Boraginaceae, Chenopodiaceae, Convolvulaceae, Fabaceae, Malvaceae, Poaceae, Portulacaceae, Solanaceae and Zygophyllaceae are present in the study site. Twenty-five weed species belonging to these botanical families were collected and identified in the site. From these, two species of the Malvaceae family with potential risk of gene flow plants, Anoda cristata and Sida hederacea were identified in the site; however, the CP4 EPSPS protein was not detected in none of the collected weed species and only the GM genotype Bollgard II' was positive to the CP4 EPSPS protein in the study site.
\end{abstract}

Keywords: genetically modified plants; transgenic proteins; biodiversity; cross contamination; gene flow

\section{Introduction}

The weeds are plants considered unwelcome mainly in human-controlled sites; are at this time present in extensive range environments around the world (Snir et al., 2015).
However, from the view point of the taxonomy, the expression weed has no botanic meaning because of a plant that is a weed in one perspective is not a weed when developing in a condition where it is in fact desired, and where one species of plant is an appreciated crop plant, another species in the same group might be a severe weed 
(Janick, 1979). The presence of weeds is one of the main problems that limit production in the cultivated species. The weeds have high adaptation to disturbed areas by agricultural activities and if they are not controlled in a timely and efficiently, reduce the yield of crops significantly.

Fiber cotton dominates the natural textile industry worldwide, refined cottonseed is used to produce high quality cottonseed oil as meal for human and animal. Gossypium is the cotton genus; it is part of the Malvaceae family that grows in more than 50 countries (Mehboob-urRahman et al., 2012). Cotton is predominantly selfpollinating plant, i.e., fertilize themselves with their own pollen, and sometimes their pollen can be transferee by insects (Cunningham, 2014). Around to 15 pest insect species infest cotton, with abundant losses and the pest insects control is an arduous and time-consuming task. The pest and weed-management use very toxic pesticides and herbicides result a public health discomfort (Bakhsh et al., 2015).

Biotechnological manipulation of several plants (genetically modified plants - GMP), improved the survived and yield of cultivate crops around the world, made it resistant to environmental stress, insects, herbicides and some diseases. This method removes the potentially unwelcome effects of linked alleles, which could be accidentally introduced into a crop gene pool in a traditional breeding program follows the Mendel' principles of genetic, as well is faster than the conventional breeding (Chapman and Burke, 2006; Juturu et al., 2015). However, the transgenes that conferee the ability to better growth and survive, could be taken for others organism, including the weeds plants (Sammons and Gaines, 2014). Potential hybridization intraspecific or interspecific could be occurs between variants or wild type, or with sexually compatible species, correspondently. The potential environmental risk is considered high between untransformed parent lines or in closely related weeds plants, moreover all the possibilities might happen (Ryffel, 2014).

Instead the first cotton genetically modified plants developed in 1996, several traits have been introduced. Insect, virus, bacteria, fungi, drought, chilling, heat, salt, and herbicide tolerance; as well as, manipulation of oil contain and fiber features have been reported (Center Environmental Risk Assessment, 2010; Bakhsh et al., 2015; Holst-Jensen et al., 2012; Emani, 2016). Developing strains glyphosate tolerant, made the culture of cotton friendly with environment. Several cotton producer countries have been adopted genetically modified varieties tolerant to herbicides (Manalil et al., 2017). Genetically modified cotton (Gossypium spp.) cover around the $70 \%$ of cultivated cotton in the United States of America (Chapman and Burke, 2006). Mexico has approved 18 GMP cotton, 17 as food and feed use. Nevertheless, Mexico is considered as primary diversity center for the genus Gossypium (Wegier et al., 2011). Therefore the potential propagation unwanted of the tolerance transgenes and keep the diversity are a national concerns, as well as essential topic for global food security (Quist and Chapela, 2001).

Gene flow of GMP crops to wild species have been reported (Rieseberg et al., 2003; Stewart et al., 2003; Warwick et al., 2003), beside with the possible persistence of the transgenes in nature (Warwick et al., 2008). In cotton the pollen-mediated gene flow in greenhouse, confirmed that the resistant phenotype to herbicides and insect were transfer, and it be determined by pollinator species, distances between plants and the receptor plant (Yan et al., 2015, Cunningham et al., 2014). Freire (2002) suggest that genetically modified cotton can have pollination with wild cotton and native plants. The principal way to introduce new genes at the native population of plants is through the movement of seed or propagules to outside of the cultivate areas; a potential crossover with other sexually compatible families is possible (Center Environmental Risk Assessment, 2010).

Particular interest has the propagation of the gen EPSPS that codified for the protein 5-enolpyruvyl shikimate-3phosphate synthase, originally isolated from one strain of Agrobacterium sp. (CP4 EPSPS), that was successfully incorporated to cotton and other crops (Harrison et al., 1996). After several field trials the genetically modified cotton strain glyphosate-tolerant has a huge potential to control weeds in cotton fields (Bakhsh et al., 2015). Indeed, the genetically modified gen is now used as selectable marker for detecting the gene flow between cultivated and native plants (Watrud et al., 2004; Weigier et al., 2011; Ryffel, 2014).

Genetically modified cotton has been sown in several part of the Mexican territory since 1996 whith subsidizes purchase for the government. In 2003, $25 \%$ of the nation was cover with GMP cotton. In 1996 the genetically modified cotton with tolerance to the herbicide glyphosate was approved in Mexico and all the farmers were be able to sown it (Vassant and Dinesh, 2016).

Reports for the cotton associated with weeds species described 126 species in Mexico; in Sonora, Mexico were described 104 weed species (Villaseñor and Espinoza, 1998) meanwhile, in San Luis Rio Colorado, Sonora, Mexico, a city located close to the border with US, 27 weed species has been recorded (Herrera-Andrade et al., 2010; Hernández et al., 2010). The objective of this study was to quantify and identify weed species associated to genetically modified cotton fields and to detect the present of glyphosateinsensitive EPSP synthases (CP4 EPSPS) in the weed species.

\section{Materials and Methods}

\section{Study area}

Delimited collecting area was plotted in the municipality of San Luis Rio Colorado, Sonora $\left(32^{\circ} 16^{\prime}\right.$ 25.54 " N; $\left.114^{\circ} 57^{\prime} 52.35^{\prime \prime} \mathrm{W}\right)$ at the Border to MexicoUSA (Fig. 1). In the agricultural cycle of 2011, two hectares were cultivated with transgenic cotton genotype Bollgard II with resistance to insects and tolerance to herbicides. One sample of each weed plant present in the experimental plot, were collected and transported to the Agricultural Biology Laboratory at the Universidad Juarez del Estado de Durango. Also, one sample of the genetically modified cotton genotype Bollgard II was collected. The botanical identification was carried out using specialized codes (Villarreal-Quintanilla, 1983; Lot and Chiang, 1986; Villaseñor and Espinosa, 1998; Elpel, 2000). 
296

\section{Detection test}

For each collected and identified weed plant, leaves were tested for the presence of CP4 EPSPS using the QuickStix TM Combo Kit for Bollgard II R/Roundup Ready R Leaf and Seed (EnviroLogix, Portland, ME, USA), as well the cotton genotype Bollgard II was used as positive control. Approximately $1 \mathrm{~cm}$ of leaf was placed into an Eppendorf tube containing $0.5 \mathrm{~mL}$ of extraction buffer. The tissues were macerated until it was completely triturated. The supernatant were transfer to a clean tube and one reactive strip was introduced in order to detect the presence of the transgene protein CP4 EPSPS in the correspondently line of the strip. Negative samples only show one line in about 4 $\mathrm{mm}$ below the top pads. Positive samples to CP4 EPSPS develop one additional band few millimeters down to the control line. This methodology was also used by Huang et al. (2007) and Yue et al. (2008).

\section{Results and Discussion}

\section{Collected weed plants}

Eleven botanical families were found in the 25 species collected of weed plants in San Luis Rio Colorado, Sonora experimental plot (Table 1) there is very close to the previous reports describing a richness of 27 species (Herrera-Andrade et al., 2010; Hernández et al., 2010). According with Booth and Swanson (2002), Perdomo et al. (2004) and Manalil et al. (2017) this difference could be due for disturbances in the land, the spatial and temporal variability in the communities and by the different strategies of cultivation. In Sonora, Mexico, Villaseñor and Espinoza (1998) reported a high number of weed species associated with the cotton agroecosystem while Martínez-Díaz and Jiménez-León (2009) reported 82 species of weeds in agricultural fields and orchards in La Costa de Hermosillo, western Sonora; only 32 species were non-natives. Also, Tamayo (2010) reported 56 weed species associated with the cotton fields in Sonora, Mexico, which include Malva parviflora from the Malvaceae family. The floristic abundance in the different ecosystems including farmlands, is associated with the cultivation practices and environmental conditions of the habitats; these attributes are important elements that define the existence of species in a site (Dauber et al., 2003), possibly because of that, the differences found in weed species at the study site were different with those reported in Sonora, Mexico. The Malvaceae family found in the experimental plots in San Luis Rio Colorado, Sonora, Mexico was represented by Anoda cristata and Sida hederacea that are the species more vulnerable to presenting gene flow with genetically modified cotton (Center Environmental Risk Assessment, 2010).

\section{Identifying of the CP4 EPSPS protein}

From the 25 weeds species identifies in the experimental plot in San Luis Rio Colorado, Sonora, Mexico; none one gave positive to the presence of CP4 EPSPS protein, using the certificated test to QuickStix TM Combo Kit for Bollgard II R/Roundup Ready $\mathrm{R}^{\circ}$ Leaf and Seed and the cotton genotype Bollgard II was the unique that presented the positive result. This finding suggest that the potential gene flow between the transgenic cotton sown for around 18 years in the region and the weed plants associated has not yet occurred, or that protein is not expressed for these plants. Similar results reported Márquez-Hernández et al. (2015) in a study done to detect the presence of the CP4 EPSPS protein in weed flora in genetically modified cotton fields in Coahuila and Durango, Mexico, who found four weed species of the Malvaceae family, Malvastrum coromandelianu, Sphaeralcea angustifolia, Anoda cristata and Sida hederaceae in both, Coahuila and Durango, Mexico,

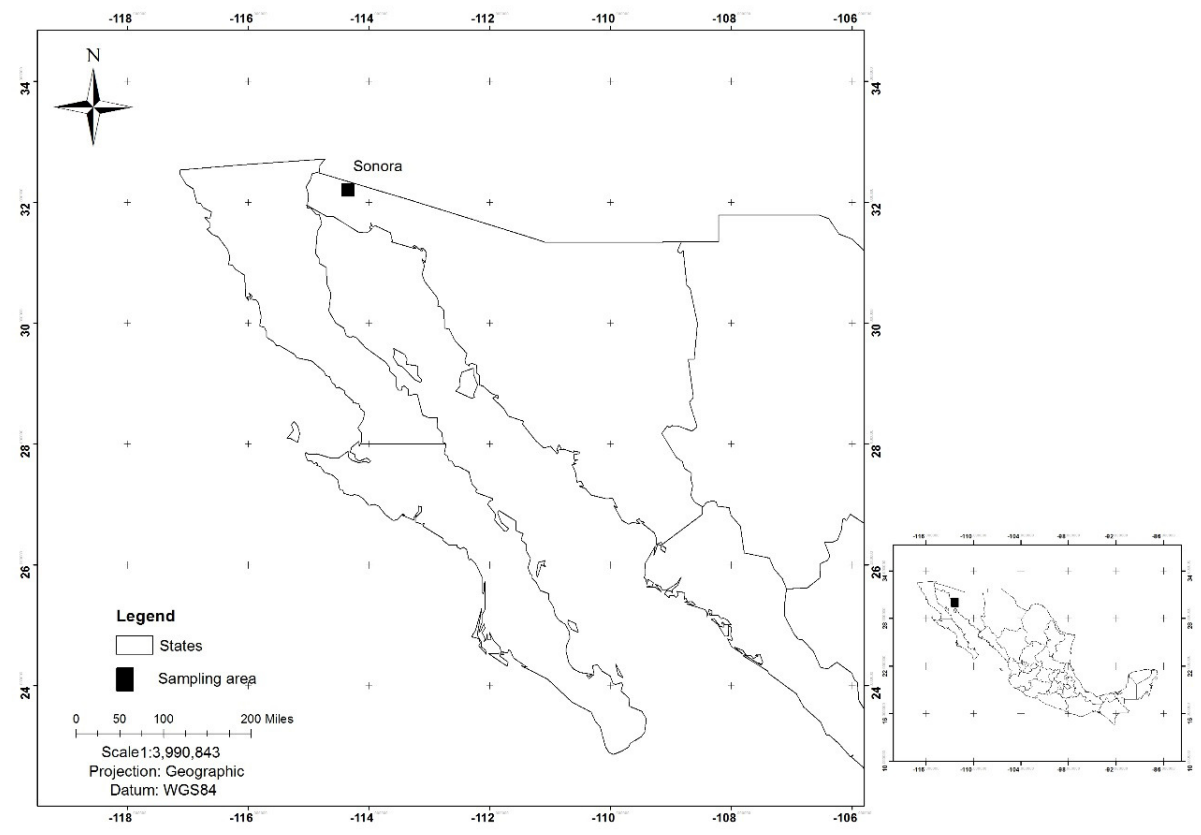

Fig. 1. Location of cultivated plots of genetically modified cotton in San Luis Rio Colorado, Sonora, Mexico 
Table 1. Presence of the CP4 EPSPS protein in weed species associated to genetically modified cotton in San Luis Rio Colorado, Sonora, Mexico

\begin{tabular}{|c|c|c|c|c|}
\hline Species number & Family & Scientific name & Control line & CP4EPSPS \\
\hline 1 & Amaranthaceae & Amaranthus hybridus & * & \\
\hline 2 & Asteraceae & Helianthus annuus & * & \\
\hline 3 & Asteraceae & Pluchea sericea & * & \\
\hline 4 & Asteraceae & Sonchus oleraceus & * & \\
\hline 5 & Asteraceae & Verbesina encelioides & * & \\
\hline 6 & Asteraceae & Xanthium strumarium & * & \\
\hline 7 & Boraginaceae & Heliotropium curassavicum & * & \\
\hline 8 & Chenopodiaceae & Chenopodium album & * & \\
\hline 9 & Chenopodiaceae & Chenopodium murale & $*$ & \\
\hline 10 & Convolvolaceae & Convolvulus arvensis & * & \\
\hline 11 & Convolvulaceae & Ipomoea purpurea & * & \\
\hline 12 & Fabaceae & Hoffmanseggia glauca & * & \\
\hline 13 & Malvaceae & Anoda cristata & * & \\
\hline 14 & Malvaceae & Sida hederacea & * & \\
\hline 15 & Poaceae & Chloris submutica & * & \\
\hline 16 & Poaceae & Cynodon dactylon & * & \\
\hline 17 & Poaceae & Echinochloa colona & * & \\
\hline 18 & Poaceae & Echinochloa crus galli & * & \\
\hline 19 & Poaceae & Eragrostis mexicana & * & \\
\hline 20 & Poaceae & Phalaris minor & * & \\
\hline 21 & Poaceae & Setaria verticillata & * & \\
\hline 22 & Poaceae & Sorghum halepense & * & \\
\hline 23 & Portulaceae & Portulaca oleracea & * & \\
\hline 24 & Solanaceae & Solanum elaeagnifolium & * & \\
\hline 25 & Zygophyllaceae & Tribulus terrestris & * & \\
\hline 26 & Malvaceae & Gossypium hirsutum & * & * \\
\hline
\end{tabular}

but the CP4 EPSPS protein was not detected in none of these weed plants located in the agroecosystem of genetically modified cotton in these study sites.

Several hypotheses allow explicating this result could be the deficient transport of pollen by wind or insects (Gómez, 2002; Guzmán et al., 2008). Other causes could be the incompatibility among the sexual form of this genetically modified seed and the native weed plants or their chromosomal complement is not productive. But also, the lack of synchrony among the susceptible species, the genetically modified cotton and their fertility periods is considered as barrier (Center Environmental Risk Assessment, 2010). Generally, the current evidence of genetic flow is the presence of fertile progeny carried the genetically modified varieties (Center Environmental Risk Assessment, 2010; Risk Assessment Search Mechanism, 2010; Mallory-Smith et al., 2015), which in this case were not detected because of that introgression of the tolerance to glyphosate was not found in weed species in the genetically modified cotton fields in San Luis Rio Colorado, Sonora, Mexico. Similar results reported Warwick et al. (2008); Mallory-Smith and Zapiola (2008) and Center Environmental Risk Assessment (2010), also, Brubaker et al. (1999) found that Australian wild cotton species fail to serve as recipients to transgenes from commercial species of Gossypium hirsutum, because of the prezygotic barriers that separate the genetically modified tetraploid cotton from their wild (diploids) Australian relatives.

\section{Conclusions}

Eleven botanical families were found in the 25 species collected of weed plants in San Luis Rio Colorado, Sonora experimental plot, which is very close to the previous reports describing a richness of 27 species associated to genetically modified cotton. From these species, Anoda cristata and Sida hederacea belong to the Malvaceae family are species identified with potential risk of gene flow plants; however the CP4 EPSPS protein no was detected in none collected weed species, including two species of the Malvaceae family. Only the GM genotype Bollgard II was positive to the $\mathrm{CP} 4$ EPSPS protein in the study site.

\section{Acknowledgements}

The authors gratefully acknowledge the assistance of Dr. Michael Matson (native speaker English) and Diana Dorantes Fisher (expert translator) for editing the English text. The corresponding author is grateful to National Council of Science and Technology of Mexico (CONACYT) by supporting the modality of sabbatical stays abroad within the framework of the national call support for sabbatical stays related to the consolidation of research groups and/or strengthening of the national postgraduate program (2017-I). 
298

\section{Authors' contributions}

JEA, JRER contributed to weed species collection; PPR, JJRP, JRER and CMH participated with analysis of laboratory, data and manuscript preparation; AT and $\mathrm{CMH}$ wrote and edited the first draft of the manuscript; BMA wrote the final version of the manuscript. All authors read and approved the final manuscript.

\section{Funding}

This study was funded by project titled "Impact of transgenic cotton in entomo-fauna diversity and weed plants in Mexico: initial study" from SEP-CONACYT (grant number 134561).

\section{References}

Bakhsh A, Emine A, Özcan SF, Hussain T, Aasim M, Khawar KM, Özcan $S$ (2015). An insight into cotton genetic engineering (Gossypium birsutum L.): current endeavors and prospects. Acta Physiologia Plantarum 37:171-179.

Booth D, Swanton J (2002). Assembly theory applied to weed communities. WeedScience 50(1):2-13.

Brubaker CL, Paterson AH, Wendel JF (1999). Comparative genetic mapping of allotetraploid cotton and its diploid progenitors. Genome 42:184203.

Center Environmental Risk Assessment-CERA (2010). A review of the environmental safety of the CP4 EPSPS protein. Center Environmental Risk Assessment, ILSI Research Foundation. Washington D.C.

Chapman MA, Burke JM (2006). Letting the gene out of the bottle: the population genetics of genetically modified crops. New Phytologist 170(3):429-443.

Cunningham SA (2014). Honeybee visitors to cotton flowers and their role in crop pollination. A literature review. Commonwealth Scientific and Industrial Research Organisation (CSIRO). Agricultural Productivity Flagship. CLW 1501, for the Cotton Research \& Development Corporation, Australia.

Dauber J, Hirsch M, Simmerring D, Waldhardt R, Otte A, Wolters V (2003). Landscape structure as an indicator of biodiversity: matrix effects on species richness. Agriculture Ecosystem and Environment 98:321329.

Elpel T (2000). Botany in a day. 5th Edition. HOPS Press.

Emani C (2016). Transgenic cotton for agronomical useful traits. In: Fiber plants: Biology, biotechnology and applications. Ramawat KG, Ahuja Cham MR(Eds).Springer International Publishingpp 201-216.

Freire E (2002). Viabilidade de cruzamentos entre algodoeiros transgênicos e comerciais e silvestres do Brasil [Viability of crosses between transgenic and commercial and wild cotton in Brazil]. Revista Oleaginosas e Fibrosas 6:465-470.

Gómez JM (2002). Generalización en las interacciones entre plantas y polinizadores [Generalization in interactions between plants and pollinators]. Revista Chilena de Historia Natural 75:105-116.
Guzmán M, San Vicente F, Díaz D (2008). Flujo de polen entre híbrido tropicales de maíz de diferentes color de endospermo [Flow of pollen between tropical maize hybrids of different color of endosperm]. Bioagro 20:159-166.

Harrison LA, Bailey MR, Naylor MW, Ream JE, Hammond BG, Nida DL, ... Padgette SR (1996). The expressed protein in gyphosatetolerant soybean, 5-Enolypyruvylshikimate-3-Phosphate Synthase from Agrobacterium sp. strain CP4, is rapidly digested in vitro and is not toxic to acutely gavaged mice. Journal of Nutrition 126(3):728-740.

Hernández VB, Alvarado PJI Ávila CE, Payan OS, Morales MA, Loza VE (2010). Guía técnica para elárea de influencia del Campo Experimental Valle de Mexicali. Sorgo Forrajero [Technical guide for the area of influence of the Mexicali Valley Experimental Field. Forage Sorghum]. Instituto Nacional de Investigaciones Agrícolas y Pecuarias. Centro de Investigación Regional del Noroeste. Campo Experimental Valle de Mexicali. Guía Técnica Número 1. 107-111.

Herrera-Andrade JL, Guzmán-Ruíz SC, Loza-Venegas E (2010). Guía para producir algodón en el Valle de Mexicali, B.C y San Luis Rio Colorado, Sonora [Guide to produce cotton in Mexicali Valley, B.C. and San Luis Rio Colorado, Sonora]. Instituto Nacional de Investigaciones Forestales Agrícolas y Pecuarias. Campo Experimental Valle de Mexicali. CIRNOROESTE-SAGARPA.

Holst-Jensen A, Bertheau Y, de Loose M, Grohmann L, Hamels S, Hougs L, ... Wulff D (2012). Detecting un-authorized genetically modified organisms (GMOs) and derived materials. Biotechnology Advances 30:1318-1335.

Huang F, Leonard RB, Cook RD, Lee RD, Andow AD, Baldwin LJ, Tindall VK, Wu X (2007). Frequency of alleles conferring resistance to Bacillus thuringiensis maize in Louisiana populations of the southwestern corn borer. Entomologia Experimental et Applicata 122:53-58.

Janick J (1979). Horticultural Science (3rd ed.). San Francisco: WH Freeman.

Juturu VN, Mekala GK, Kirti PB (2015). Current status of tissue culture and genetic transformation research in cotton (Gossypium spp.). Plant Cell Tissue and Organ Culture 120:813-839.

Lot A, Chiang F (1986). Manual del herbario [Herbarium manual]. Consejo Nacional dela Flora de México. México.

Mallory-Smith C, Hall LM, Burgos NR (2015). Experimental methods to study gene flow. Weed Science 63(1):12-22.

Mallory-Smith C, Zapiola M (2008). Gene flow from gyphosate-resistant crops. Pest Management Science 64(4):428-440.

Manalil S, Coast O, Werth J, Chauhan BS (2017). Weed management in cotton (Gossypium hirsutum L.) through weed-crop competition: A review. Crop Protection 95:53-59.

Márquez-Hernández C, Puente-Valenzuela CO, Muro-Pérez G, GarcíaHernández JL, Rueda-Puente EO, Moreno-Hernández AN (2015). Detección de la proteína CP4 EPSPS en plantas arvenses en cultivos de algodón (Gossypium hirsutum) transgénico en la Comarca Lagunera, México [Detection of CP4 EPSPS protein in weed flora in transgenic cotton (Gossypium hirsutum) crops in Comarca Lagunera, México]. Agrociencia 49:739-747. 
Martínez-Díaz G, Jiménez-León J (2009). Weeds in agricultural crops in La Costa de Hermosillo, Sonora, Mexico. In: Van Devender TR, EspinosaGarcía FJ, Harper-Lore BL, Hubbard T (Eds). Invasive plants on the move. Controlling them in North America. Proceedings of Weeds Across Borders Conference, Hermosillo, Sonora, May 25-28, 2006. Arizona-Sonora Desert Museum, Tucson, Arizona, USA pp 199-208.

Mehboob-ur-Rahman, Shaheen T, Tabbasam N, Iqbal MA, Ashraf M, Zafar Y, Paterson AH (2012). Cotton genetic resource. A review. Agronomy for Sustainable Development 32:419-432.

Perdomo F, Vibrans L, Romero M, Domínguez V, Medina J (2004). Análisis de SHE, una herramienta para estudiar la diversidad de malezas [Analysis of SHE, a tool to study the diversity of weeds]. Revista Fitotecnia Mexicana 27:57-61.

Quist D, Chapela HI (2001). Transgenic DNA introgressed into traditional maize landraces in Oaxaca, México. Nature 414:541-543.

Rieseberg LH, Raymond O, Rosenthal DM, Lai Z, Livinstone K, Nakazato $T$, ... Lexer C (2003). Major ecological transitions in wild sunflowers facilitated by hybridization. Science 301:1211-1216.

Risk Assessment Search Mechanism (2017). Risk Assessment Search Mechanism - RASM. Retrieved 2017 January 01 from http://rasm.icgeb.org/.

Ryffel GU (2014). Transgene flow: Facts, speculations and possible countermeasures. GM Crops and Food 5(4):249-258.

Sammons RD, Gaines TA (2914). Glyphosate resistance: state of knowledge. Pest Management Science 70(9):1367-1377.

Snir A, Nadel D, Groman-Yaroslavski I, Melamed Y, Sternberg M, BarYosef $\mathrm{O}$, Weiss $\mathrm{E}$ (2015). The origin of cultivation and proto-weeds, long before Neolithic farming. PLoSOne 10(7):e0131422.

Stewart C, Halfhill M, Warwick S (2003). Transgene introgression from genetically modified crops to their wild relatives. Nature Reviews Genetics 4:806-817.

Tamayo ELM (2010). Principales malezas en el Sur de Sonora y de la región de Caborca [Main weeds in the South of Sonora and Caborca region]. Instituto Nacional de Investigaciones Forestales Agrícolas y Pecuarias, Campo Experimental Valle del Yaqui. Ciudad Obregón, Sonora, México.

Vassant PG, Dinesh J (2016). Introduction of biotechnology in India's agriculture: Impact, performance and economics. Springer Nature. SpringerScience+Business MediaSingapore Pte Ltd.
Villarreal-QuintanillaJA(1983). Malezas de Buenavista Coahuila [Weeds of Buenavista, Coahuila]. Universidad Autónoma Agraria Antonio Narro. Saltillo, Coahuila.

Villaseñor R, Espinosa G (1998). Catálogo de malezas de México [Catalogue of weeds of Mexico]. Universidad Nacional Autónoma de México. Fondo de Cultura Económica.

Warwick I, Legere A, Simard J, James T (2008). Do escaped transgenes persist in nature? The case of an herbicide resistance transgene in a weedy Brassica rapa population. Molecular Ecology 17:1387-1395.

Warwick SI, Simard MJ, Légère A, Beckie HJ, Braun L, Zhu B, ... Stewart JrCN (2003). Hybridization between transgenic Brassica napus L. and its wild relatives: Brassica rapa L., Raphanus raphanistrum L., Sinapis arvensis L., and Erucastrum gallicum (Willd.) O.E. Schulz. Theoretical and Applied Genetics 107:528-539.

Watrud LS, Lee EH, Fairbrother A, Burdick C, Reichman JR, Bollman M, Storm M, King G, Van der Water PK (2004). Evidence for landscapelevel, pollen-mediated gene flow from genetically modified creeping bentgrass with CP4 EPSPS as a marker. Proceedings of the National Academy of Sciences of the United States of America 101(40): 1453314538.

Wegier A, Pineyro-Nelson A, Alarcon J, Galvez-Mariscal SA, Alvarez-Buylla ER, Pinero D (2011). Recent long-distance transgene flow into wild populations conforms to historical patterns of gene flow in cotton (Gossypium birsutum) at its centre of origin. Molecular Ecology 20:4182-4194.

Yan S, Zhu J, Zhu W, Li Z, Shelton AM, Luo J, Cui J, Zhang Q, Liu X (2015). Pollen-mediated gene flow from transgenic cotton under greenhouse conditions is dependent on different pollinators. Scientific Reports 5:15917.

Yue B, Huang F, Leonard BR, Moore S, Parker R, Andow AD, Cook D, Emfinger K, Lee RD (2008). Verifying an F1 screen for identification and quantification of rare Bacillus thuringiensis resistance alleles in field populations of the sugarcane borer Diatraea saccharalis. Entomologia Experimental et Applicata 129:172-180. 